\title{
Co-expression of RON and MET is a prognostic indicator for patients with transitional-cell carcinoma of the bladder
}

\author{
H-L Cheng ${ }^{1,7}$, H-S Liu' ${ }^{2,7}$, Y-J Lin' ${ }^{2}$, HH-W Chen ${ }^{3}$, P-Y Hsu ${ }^{4}$, T-Y Chang ${ }^{5}$, C-L Ho ${ }^{4,6}$, T-S Tzai' and N-H Chow ${ }^{*, 4,6}$ \\ 'Department of Urology, National Cheng Kung University, I Ta-Hsueh Road, Tainan 70428, Taiwan; ${ }^{2}$ Departments of Microbiology and Immunology, \\ National Cheng Kung University, I Ta-Hsueh Road, Tainan 70428, Taiwan; ${ }^{3}$ Department of Radiation Oncology, National Cheng Kung University, I Ta- \\ Hsueh Road, Tainan 70428, Taiwan; ${ }^{4}$ Institute of Basic Medical Sciences, National Cheng Kung University, I Ta-Hsueh Road, Tainan 70428, Taiwan; \\ ${ }^{5}$ Department of Parasitology, National Cheng Kung University, I Ta-Hsueh Road, Tainan 70428, Taiwan; ${ }^{6}$ Department of Pathology, National Cheng \\ Kung University, I Ta-Hsueh Road, Tainan 70428, Taiwan
}

Recepteur d'Origine Nantais (RON) is a distinct receptor tyrosine kinase in the c-met proto-oncogene family. We examined the mutational and expression patterns of RON in eight human uroepithelial cell lines. Biological effects of RON overexpression on cancer cells were investigated in vitro, and the prognostic significance of RON and/or c-met protein (MET) expression was analysed in a bladder cancer cohort $(n=183)$. There was no evidence of mutation in the kinase domain of RON. Overexpression of RON using an inducible Tet-off system induced increased cell proliferation, motility, and antiapoptosis. Immunohistochemical analysis showed that RON was overexpressed in 60 cases (32.8\%) of primary tumours, with I 4 (23.3\%) showing a high level of expression. Recepteur d'Origine Nantais expression was positively associated with histological grading, larger size, nonpapillary contour, and tumour stage (all $P<0.0$ I). In addition, MET was overexpressed in 82 cases (44.8\%). Co-expressed RON and MET was significantly associated with decreased overall survival $(P=0.005)$ or metastasis-free survival $(P=0.01)$ in 35 cases (19.1\%). Recepteur d'Origine Nantaisassociated signalling may play an important role in the progression of human bladder cancer. Evaluation of RON and MET expression status may identify a subset of bladder-cancer patients who require more intensive treatment.

British Journal of Cancer (2005) 92, 1906-19|4. doi:10.1038/s.bjc.6602593 www.bjcancer.com

Published online 3 May 2005

(c) 2005 Cancer Research UK

Keywords: bladder cancer; protein tyrosine kinases; RON; MET; co-expression; prognosis

Protein tyrosine kinases (PTKs) are a major class of protooncogenes and play a crucial role in many cell regulatory processes, such as proliferation, migration, adhesion, and, potentially, cellular transformation. Currently, most of the established proto-oncogenes in solid tumours are PTKs. The type-1 ErbB family receptors - epidermal growth factor (EGF) receptor and ErbB2 (c-erbB-2, HER-2/neu) - are well-known examples. Dimerisation by binding two monomers is the regulatory mechanism for the activation of tyrosine kinase receptors (Heldin, 1995). In some cases, formation of heterodimeric complexes allows interaction and cross-talk between different receptors of the same subfamily, and the ErbB receptor family is the best example of homo- and hetero-dimerisation in vivo (Wada et al, 1990; Sliwkowski et al, 1994; Pinkas-Kramarski et al, 1996; Chow et al, 2001). Therefore, determining the clinical significance of the co-expression pattern of PTKs can provide important molecular targets for cancer therapy.

Recepteur d'Origine Nantais (RON), also known as stem-cellderived tyrosine kinase in mice, is a distinct receptor tyrosine

*Correspondence: Dr N-H Chow, Department of Pathology, National Cheng Kung University Hospital, 138 Sheng-Li Road, Tainan 70428, Taiwan; E-mail: chownh@mail.ncku.edu.tw

7 These two authors contributed equally to this study

Received 27 October 2004; revised 7 March 2005; accepted 24 March 2005; published online 3 May 2005 kinase in the MET proto-oncogene family (Ronsin et al, 1993). The ligand for RON was identified as macrophage-stimulating protein (MSP) (Wang et al, 1994), expressed by renal tubular cells (Rampino et al, 2002). Recepteur d'Origine Nantais induces cell transformation and epithelial tumorigenesis (Collesi et al, 1996; Santoro et al, 1996; Peace et al, 2001; Chen et al, 2002). In primary human cancer, highly expressed RON was observed in $47 \%$ (35 of 74 cases) of breast cancers and $59.2 \%$ (29 of 49 cases) of colorectal cancers (Maggiora et al, 1998; Zhou et al, 2003).

In our prior profiling experiment (Cheng et al, 2002), RON was one of the receptor-type PTKs expressed in bladder cancer cells. Interestingly, this receptor protein and its cognate ligand MSP are all located within chromosome $3 \mathrm{p} 21.3$, a region frequently amplified in human bladder cancer (Koo et al, 1999). As crosstalk between RON and MET was observed in epithelial cancer (Chen et al, 1997; Maggiora et al, 2003), we investigated the clinical significance of RON and MET overexpression in human bladder cancer.

\section{MATERIALS AND METHODS}

\section{Immunoprecipitation}

Urine samples $(n=32)$ were concentrated using a centrifugal filter device with a molecular weight cutoff of $50 \mathrm{kDa}$ (UltraFree-4; Millipore, Bedford, MA, USA) as described previously (Yan et al, 
2001). Protein concentrations of the concentrated urine samples were determined using the Micro BCA method (Pierce Chemical, Rockford, IL, USA). Equal amounts of proteins $(20 \mu \mathrm{g})$ were loaded onto $4-15 \%$ gradient gels and separated using sodium dodecyl sulphate (SDS)-polyacrylamide gel electrophoresis under nonreducing conditions. Resolved proteins were electrophoretically transferred to TransBlot nitrocellulose membranes (Bio-Rad, Richmond, CA, USA). The membranes were blocked with $5 \%$ low-fat dry milk in TBS-T (10 mM Tris, pH 7.2, $50 \mathrm{~mm} \mathrm{NaCl}, 0.5 \%$ Tween 20) for $1 \mathrm{~h}$ at room temperature, followed by incubation with primary antibody (1:100 dilution) against human $\operatorname{MSP} \alpha$ (R\&D Systems, Minneapolis, MN, USA) at $4^{\circ} \mathrm{C}$ for $18 \mathrm{~h}$. Blots were washed eight times with TBS-T (5 min per wash) and incubated with a 1:5000 dilution of horseradish peroxidase-conjugated secondary antibody (Vector Laboratories, Inc., Burlingame, CA, USA) diluted in TBS-T containing 3\% bovine serum albumin for $1 \mathrm{~h}$ at room temperature. Labelled proteins were visualised with enhanced chemiluminescence (Amersham Biosciences Corp., Piscataway, NJ, USA). Cell lysates from HepG2 and UB37 were used as positive controls. Informed consent was obtained from all patients before their urine was taken for analysis.

\section{Cell lines and culture}

Four human bladder cancer cell lines (RT4, TSGH-8301, TCC-SUP, and T24) were propagated for use, as described previously (Cheng et al, 2002). The locally established cell lines UB09, UB37, UB40, and UB47 were derived from transitional-cell bladder cancer of grade II pT2, grade III pT3, grade III pT1, and grade III pT3, respectively. They were maintained in Dulbecco's modified Eagle's medium (DMEM) (Gibco BRL, Grand Island, NY, USA) supplemented with $10 \%$ foetal calf serum (Gibco BRL), L-glutamine $\left(2 \mathrm{mmoll}^{-1}\right)$, sodium pyruvate $\left(110 \mathrm{mgl}^{-1}\right)$, penicillin $\left(100 \mathrm{U} \mathrm{ml}^{-1}\right)$, and streptomycin $\left(50 \mathrm{~g} \mathrm{ml}^{-1}\right)$ at $37^{\circ} \mathrm{C}$ in a $5 \%-\mathrm{CO}_{2^{-}}$ humidified atmosphere. Primary culture of uroepithelium was obtained from a patient with non-neoplastic urinary disease, and maintained in keratinocyte-SFM (Gibco BRL), supplemented with bovine pituitary extract $\left(20-30 \mu \mathrm{g} \mathrm{ml}^{-1}\right), 10 \%$ foetal calf serum (Gibco BRL), and EGF $\left(0.1-0.2 \mathrm{ng} \mathrm{m}^{-1}\right.$ ) as described previously (Adam et al, 2003).

\section{Chemicals and plasmids}

Wortmannin was obtained from Sigma (Sigma-Aldrich, St Louis, MO, USA). Plasmid pLP-TRE2-RON was constructed in our laboratory, and co-transfected with pTet-Lac-Hygo in the subsequent experiments as described (Chow et al, 2003). In this study, the Tet-off system using doxycycline was used to regulate exogenous RON expression.

\section{Preparation of total RNA and real-time polymerase chain reaction ( $R T$ - PCR) analysis}

Total RNA was extracted using Trizol reagent (Invitrogen Corp., Carlsbad, CA, USA). First-strand cDNA was synthesised in a total volume of $20 \mu \mathrm{l}$ using an M-MLV Reverse Transcriptase kit (Invitrogen). The Roche LightCycler Real-time PCR system (Roche Diagnostics Corporation, Roche Applied Science, Indianapolis, IN, USA) was used to quantify the expression of target genes with SYBR Green I labelling. Polymerase chain reactions were performed in a total volume of $10 \mu \mathrm{l}$ containing $3 \mu \mathrm{l}$ cDNA (1:100 dilution), $2.5 \mathrm{mM} \mathrm{MgCl}_{2}, 10 \mathrm{pM}$ forward and reverse primers, $1 \mu \mathrm{l}$ SYBR Green I, and $4.8 \mu \mathrm{l}$ PCR-grade $\mathrm{H}_{2} \mathrm{O}$. The reaction was performed for $7 \mathrm{~min}$, to denature DNA and activate the Hot-Start polymerase, followed by 50 PCR cycles denatured at $95^{\circ} \mathrm{C}$ for $10 \mathrm{~s}$, annealed at $60^{\circ} \mathrm{C}$ for $5 \mathrm{~s}$, and elongated at $72^{\circ} \mathrm{C}$ for $12 \mathrm{~s}$ in glass capillaries. The primers used were: RON receptor forward 5'-AGCCCACGCTCAGTGTCTAT-3', RON receptor re- verse $5^{\prime}$-GGGCACTAGGATCATCTGTCA-3'; PPIA forward $5^{\prime}$ GTTTGCAGACAAGGTCCCA- $3^{\prime}$, and PPIA reverse $5^{\prime}$-ACCCGTAT GCTTTAGGATG-3'.

\section{Western blot analysis}

In all, $50 \mu \mathrm{g}$ of total protein was denatured in SDS lysis buffer (Tris- $\mathrm{HCl}(50 \mathrm{~mm}), \mathrm{pH} 6.8$, SDS (2\%), glycerol (10\%), and dithiothreitol $(100 \mathrm{~mm})$ ) and then loaded into duplicated $12 \%$ SDS-polyacrylamide gels. After electrophoresis, one of the gels was stained with $0.5 \%$ colorimetric Coomassie brilliant blue (Sigma) as a quantitative control. The other gel was transferred to a polyvinylidene difluoride membrane (Stratagene, La Jolla, CA, USA) and blocked with 5\% skimmed milk in PBST (sodium chloride (100 mM), disodium hydrogen phosphate ( $80 \mathrm{~mm})$, sodium dihydrogen phosphate $(20 \mathrm{~mm})$, Tween $20(0.2 \%)$, $\mathrm{pH} 7.5)$ solution at $4{ }^{\circ} \mathrm{C}$ overnight. After being washed with PBST and phosphatebuffered saline, the membrane was hybridised with the monoclonal antibodies for MET, RON, or $\beta$-actin (Santa Cruz Biotechnology, Inc., Santa Cruz, CA, USA) at $37^{\circ} \mathrm{C}$ for $1 \mathrm{~h}$. The membrane was then incubated with anti-rabbit or anti-mouse IgG conjugated with horseradish peroxidase at $25^{\circ} \mathrm{C}$ for $1 \mathrm{~h}$. After being thoroughly washed, the membrane was exposed to radiographic film following a reaction with enhanced chemiluminescence detection reagents (Amersham). Human $\beta$-actin was used as an internal control.

\section{Single-strand conformation polymorphism analysis and mutation analysis of the RON gene}

Each exon of the kinase domain, plus a region containing the proteolytic cleavage site in exon 1 , was examined for mutation using a specific PCR primer pair as described previously (Angeloni et al, 2000). First-strand cDNAs from primary uroepithelium, UB40, and UB47 cells were prepared using reverse transcription of $1 \mu \mathrm{g}$ of RNA, according to the instructions for the SuperScript preamplification system (Gibco BRL). The primers used for amplification of RON for PCR were chosen from a prior report (Collesi et al, 1996). To check for potential mutations of RON, genomic DNA was also amplified using two primers flanking this region: sense oligomer corresponding to nucleotides 2619-2641 ( $5^{\prime}$-ATCCACCCAGTGCCAACCTAGTT- $\left.3^{\prime}\right)$ and antisense oligomer corresponding to nucleotides 2873-2895 (5'-GGCCAGATGGGGT CCCACA GAG-3') (Collesi et al, 1996). Each sequence was confirmed with two independent PCR reactions.

\section{Cell viability staining}

The cells were re-suspended in DMEM medium. Equal volumes of cell suspension and ethidium-bromide/acridine-orange solution were mixed and placed underneath the cover slides. The cells were observed under a microscope. The live cells labelled with acridine orange are green, and the dead cells labelled with ethidium bromide are orange. The cells were counted and their viability was calculated.

\section{Wound-healing assay}

The UB09 cells $\left(3 \times 10^{6}\right)$ were seeded on a $30-\mathrm{mm}$ dish overnight after transfection. A mid-line wound was made on the monolayer cells, and the healing process was recorded every $20 \mathrm{~min}$ until the wound was completely healed (Ho et al, 2005). The Image-Pro plus computer program (Media Cybernetics, San Diego, CA, USA) was used to calculate the distance between the wounded edges.

\section{Clinicopathologic characteristics}

For this study, archival blocks were collected from 183 patients (117 men and 66 women; age range: $23-93$ years old; mean age: 
$64.2 \pm 10.4$ years) with primary TCC of the urinary bladder treated at our hospital between July 1, 1988, and July 31, 1994. Patients with primary carcinoma in situ were excluded from this study. The study protocol was approved by the Human Investigations Committee in our hospital. All cases were reviewed for histological grade according to the World Health Organization classification (Eble et al, 2004). Clinical staging was determined according to the Tumor-Node-Metastasis System of the Union Internationale Contre le Cancer (Sobin and Wittekind, 2002) using a survey of the clinical details, image studies, and pathologic data. But no definite tumour staging could be determined at diagnosis in 10 patients $(5.5 \%)$. This cohort was different from our prior study on MET (Cheng et al, 2002).

The treatment and follow-up of patients were conducted according to the standard strategy previously described in detail (Cheng et al, 2002). Briefly, all patients with superficial bladder cancer $(n=93)$ received transurethral resection and postoperative intravesical chemotherapeutic agent instillation with either thiotepa (30 mg in $30 \mathrm{ml}$ of normal saline for 70 patients) or epirubicin ( $40 \mathrm{mg}$ in $40 \mathrm{ml}$ of normal saline for 34 patients) weekly for 8 consecutive weeks. Those patients who received intravesical bacillus Calmette-Guerin therapy or neoadjuvant chemotherapy were excluded from this study to preclude any potential bias in prognostic correlation (e.g. recurrence rate or tumour progression). The patients were followed up every 3 months for the first 2 years, every 6 months for another 2 years, and yearly thereafter. Recurrent tumours were confirmed by biopsy, and the patient was given a transurethral operation. This was followed by another 8-week course of intravesical chemotherapeutic instillation therapy or by a radical or partial cystectomy if there was disease progression. Disease progression at recurrence was defined as being at a higher stage than the previous result. In all, 77 patients with muscle-invasive tumours were given a radical cystectomy, and nine patients were given a partial cystectomy. The four patients with distant metastasis at diagnosis received a transurethral resection only. A total of 75 patients received systemic chemotherapy with methotrexate (MTX), cisplatin, doxorubicin, and vinblastine. Survival status was determined by checking outpatient clinic records, interviewing patients' families, or both. Clinical follow-up ranged from 24 to 95 months (median: 54 months).

\section{Immunohistochemistry (IHC) of RON and MET expression}

Immunostaining procedures were described previously (Cheng et al, 2002). Briefly, tissue sections were incubated at room temperature for $2 \mathrm{~h}$ with monoclonal anti-MET and anti-RON antibodies (Santa Cruz Biotechnology) raised against human MET or RON protein, respectively. The optimal dilution $(1: 100)$ was determined using human kidney tissue as a positive control (Rampino et al, 2002). The StrAviGen Super Sensitive MultiLink kit (BioGenex Laboratories, Inc., San Ramon, CA, USA) was used to detect the resulting immune complex. Peroxidase activity was visualised using an aminoethyl carbazole substrate kit (Zymed Laboratories, Inc., San Francisco, CA, USA). Finally, sections were counterstained with haematoxylin. For the negative control, nonimmune mouse immunoglobulin was substituted for the primary antibody in the incubation.
When they evaluated the staining results, the reviewers (N-HC and C-LH) were blinded to the clinical outcomes. Since there was no apparent difference in staining intensity, we used a threecategory scoring system for RON and MET based on the proportion of tumour cells stained, as described previously (Chow et al, 2001; Cheng et al, 2002). 'High level of expression' indicates that more than $50 \%$ of the tumour cells exhibited immunostaining; 'low level of expression', between $10 \%$ and $50 \%$ reactivity; and 'negative', less than $10 \%$ or zero staining for RON protein.

\section{Statistics}

Correlations between RON or MET expression and clinicopathologic indicators of bladder cancer, and the biological effects of RON expression on cancer cells were examined, where suitable, using analysis of variance, Fisher's exact test, or $\chi^{2}$ test. The relationship between IHC expression pattern or biological indicators and clinical outcome was analysed using a multiple logistic regression model. Overall survival was calculated using Kaplan-Meier analysis, and the Cochran-Mantel-Haenszel test (log-rank test) was used to assess the significance of RON and MET expression in relation to tumour recurrence or patient survival. The relative risk (RR) in relation to patient prognosis was assessed using a Cox proportional hazards model after adjustment for clinicopathologic parameters. Only those variables with a $P$-value $<0.05$ were considered significant.

\section{RESULTS}

\section{Measurement of MSP in human urine}

To examine the involvement of MSP/RON signalling in bladder carcinogenesis, we analysed the appearance of urinary MSP in a total of 17 cases of urothelial carcinomas (two grade 1, nine grade 2 , and six grade 3) and 15 cases of non-neoplastic inflammatory urinary tract diseases. Immunoprecipitation showed that 10 of 17 with cancer and one with an inflammatory urinary tract disease had detectable urinary MSP $(P=0.04)$. Representative results of cancer $(n=9)$ and xanthogranulomatous pyelonephritis $(n=1)$ cases are shown in Figure 1. The appearance of urinary MSP was basically independent of the RON expression status in primary tumours (data not shown). These results imply that the activation of MSP/RON may be involved in the development of human bladder cancer.

\section{Expression of RON and MET receptors in uroepithelial cell lines}

The expression of RON was examined at the mRNA level using RT - PCR in a primary culture of uroepithelium and eight cancer cell lines (Figure 2). TCCSUP had the highest level of RON expression in this panel, while the other seven cancer cell lines had variable level of RON expression, with RT4 being the lowest one. Unexpectedly, primary culture of uroepithelium was found to have high RON expression.

Then, expression of RON was assessed at protein level using Western blot (Figure 3). Primary uroepithelial cells and seven of

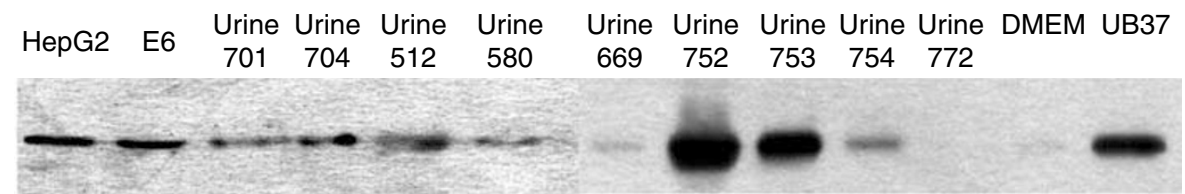

Figure I Immunoprecipitation of MSP in human urine. All nine patients with transitional-cell bladder cancer had detectable MSP in their urine, but MSP was not measurable in the urine of patients with xanthogranulomatous pyelonephritis (case 772). The column of DMEM was taken from medium used for culturing of HepG2 and UB37 cells. 


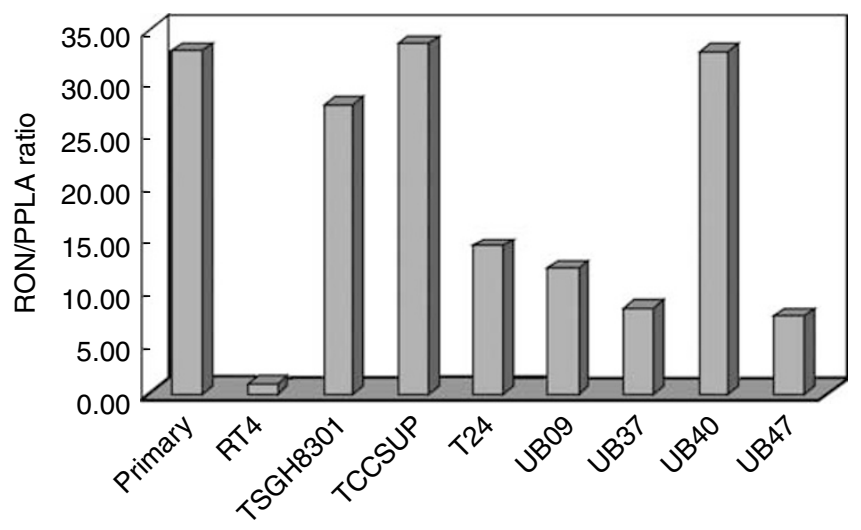

Figure 2 Reverse transcriptase-polymerase chain reaction measurement of RON expression at mRNA level. TCCSUP had the highest level of $\mathrm{RON}$ expression in this panel of uroepithelial cell culture, while the other seven cancer cell lines had variable levels of RON expression, with RT4 being the lowest one. Primary culture of uroepithelium was found to have unusually high RON expression. All reactions were performed in triplicate. Data are expressed as relative amounts of RON mRNA levels in relation to PPIA.
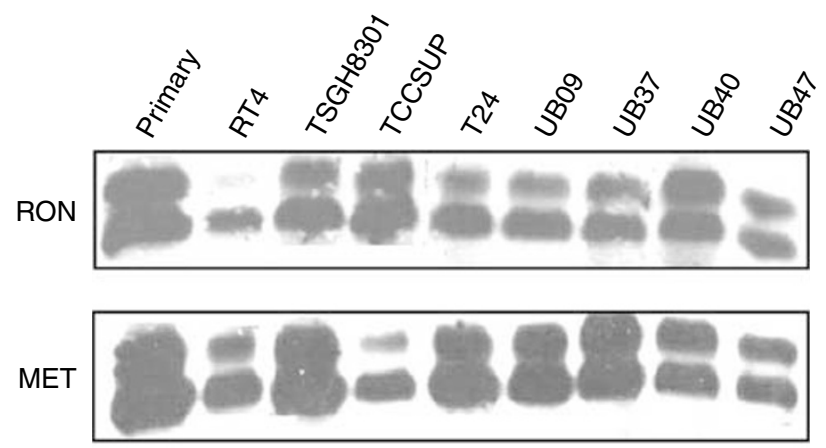

$\beta$-Actin

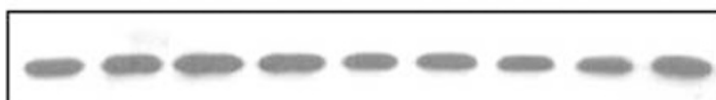

Figure 3 Expression of RON and MET receptor proteins in uroepithelial cells. Primary culture of uroepithelial cells and seven cancer cell lines expressed a mature form of pI50RON and a precursor p $180^{\mathrm{RON}}$, except that RT cells had very low level of RON expression. All the uroepithelial cells expressed mature pI40MET and precursor pI70MET, except that TCCSUP cells expressed a relatively lower level of precursor p $170^{\mathrm{MET}}$. These results indicate that co-expression of RON and MET is a universal event in uroepithelial cells.

the eight cancer cell lines expressed both the mature form of p150RON and precursor p180RON, except that RT cells had very low level of RON expression. All of the UB series cancer cell lines expressed RON protein. The expression pattern in Western blot basically corresponds to that of RT-PCR. These results suggest that RON-associated signalling events play an important role in the progression of bladder cancer.

However, we have no complete rationale to explain for high level of RON expression in primary culture of uroepithelial cells. A prior study using SV40 large-T antigen immortalised UROtsa cells showed that cells grown in serum-free growth conditions have a phenotype most like the intermediate layers of the urothelium (Rossi et al, 2001). Therefore, it is plausible to speculate that primary culture grown in serum-enriched media may exhibit a distinctly different phenotype.

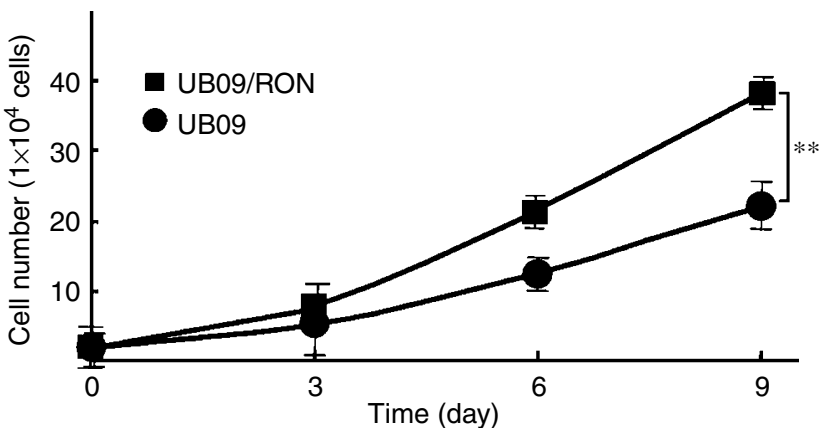

Figure 4 Growth curve of UB09 cells after transfection of RON. The cells $\left(1 \times 10^{4}\right.$ per well for six wells) were cultured in $10 \%$ serum-containing medium with or without doxycycline $\left(\mid \mu \mathrm{g} \mathrm{m}^{-1}\right)$. The cell number was calculated from 3 to 9 days using a cell counter. Those cells expressing higher RON had a significantly faster growth rate, as indicated by asterisks $(P=0.0028, t$-test $)$

A UB09/RON UB09
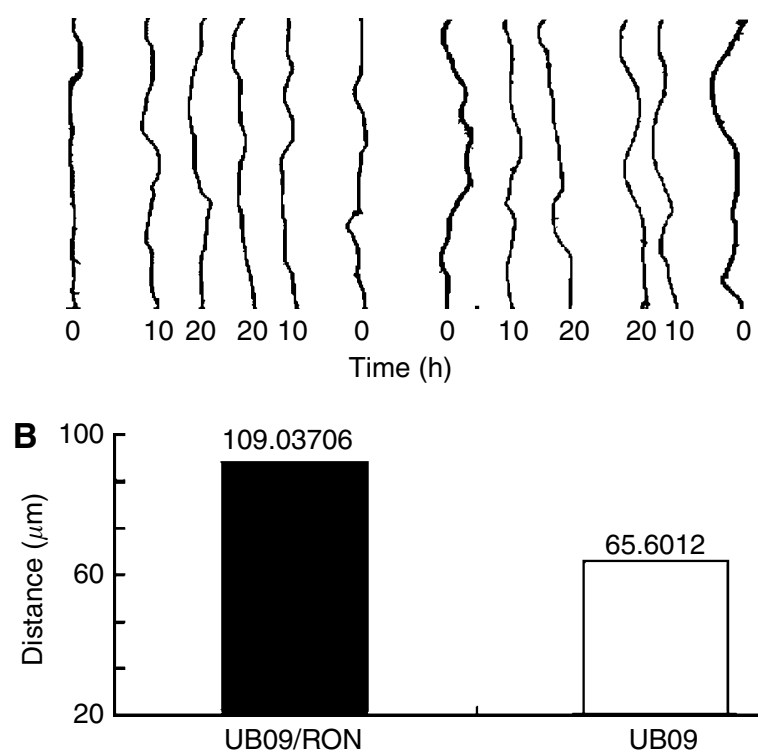

Figure 5 Time-lapse recording of cell migration in UB09 cells after transfection of RON. The cells $\left(5 \times 10^{5}\right)$ were plated on a $\mathrm{I}-\mathrm{cm}$ cover slide and grown for I day, during which the cells formed a monolayer. Cells were then wounded with a yellow tip. The healing of the wounds was recorded every $20 \mathrm{~min}$ for a total of $20 \mathrm{~h}$. (A) Distance of wounding of UB09/RON and UB09 cells, respectively. (B) Quantitative data of migration distance for UB09/RON and UB09 cells, respectively. Overexpression of RON increased the migration distance, symbolic for cell motility, of cancer cells $(P=0.04, t$-test $)$.

To determine whether constitutive activation of RON is caused by mutations in the kinase domain of RON, genomic DNA was submitted for single-strand conformational polymorphism screening using a panel of intron-based primers covering exon 1 and exons $14-20$ of the RON gene. The amplified DNA fragments were also sequenced. No mutations were found in the kinase domain of the RON gene in any of the cell lines tested (Chow et al, 2003).

All of the uroepithelial cells expressed mature p140 ${ }^{\mathrm{MET}}$ and precursor $\mathrm{p} 170^{\mathrm{MET}}$, except that a relatively lower level of $\mathrm{p} 170^{\mathrm{MET}}$ was observed in TCCSUP cells (Figure 2). Altogether, coexpression of RON and MET was a universal event in uroepithelial cells, highly suggestive of the potential clinical significance of crosstalk between RON and MET. 
A Methotrexate $\left(50 \mu \mathrm{g} \mathrm{ml}^{-1}\right.$ per $\left.72 \mathrm{~h}\right)$

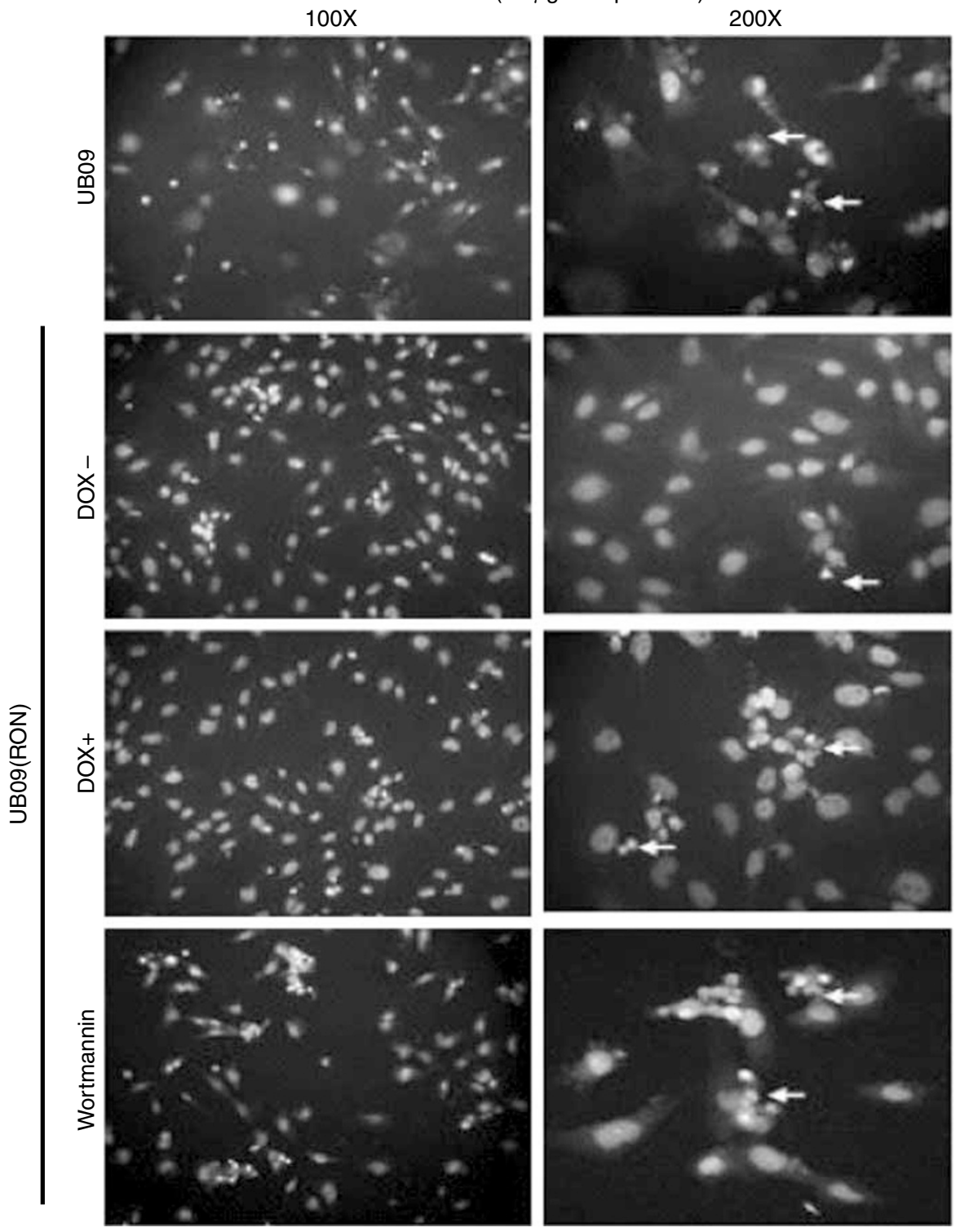

B

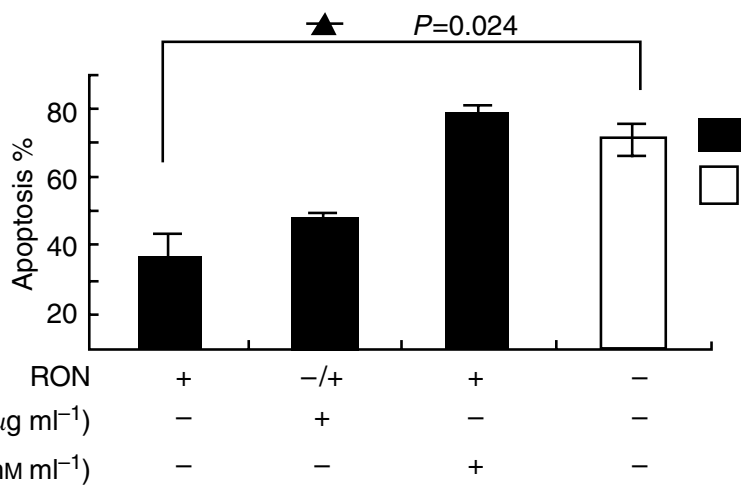

Figure 6 Antiapoptosis by acridine orange staining of the UB09/RON cells after MTX treatment. (A) UB09 cells were electroporated with $40 \mu$ g of pLPTRE2-RON and $40 \mu \mathrm{g}$ of pTet-Lac-Hyg for $12 \mathrm{~h}$. Cells were first cultured in serum-containing medium for $12 \mathrm{~h}$. Then that medium was replaced with medium containing only MTX $\left(50 \mu \mathrm{g} \mathrm{ml}^{-1}\right)$, MTX and doxycycline $\left(\mathrm{I} \mu \mathrm{g} \mathrm{ml}^{-1}\right)$, and, finally, wortmannin ( $\left.0 \mathrm{~nm}\right)$, MTX, and doxycycline for $60 \mathrm{~h}$ each. All the cells were fixed with methanol for 15 min and stained with $1 \%$ acridine orange for 10 min. Cells were examined using fluorescent microscopy (left: $\times 100$; right: $\times 200$ ). Apoptotic cells are indicated by arrows. (B) Levels of apoptotic cells measured using apoptotic body calculation in three different fields were compared in relation to doxycycline or wortmannin treatment $(P=0.024, t$-test). 

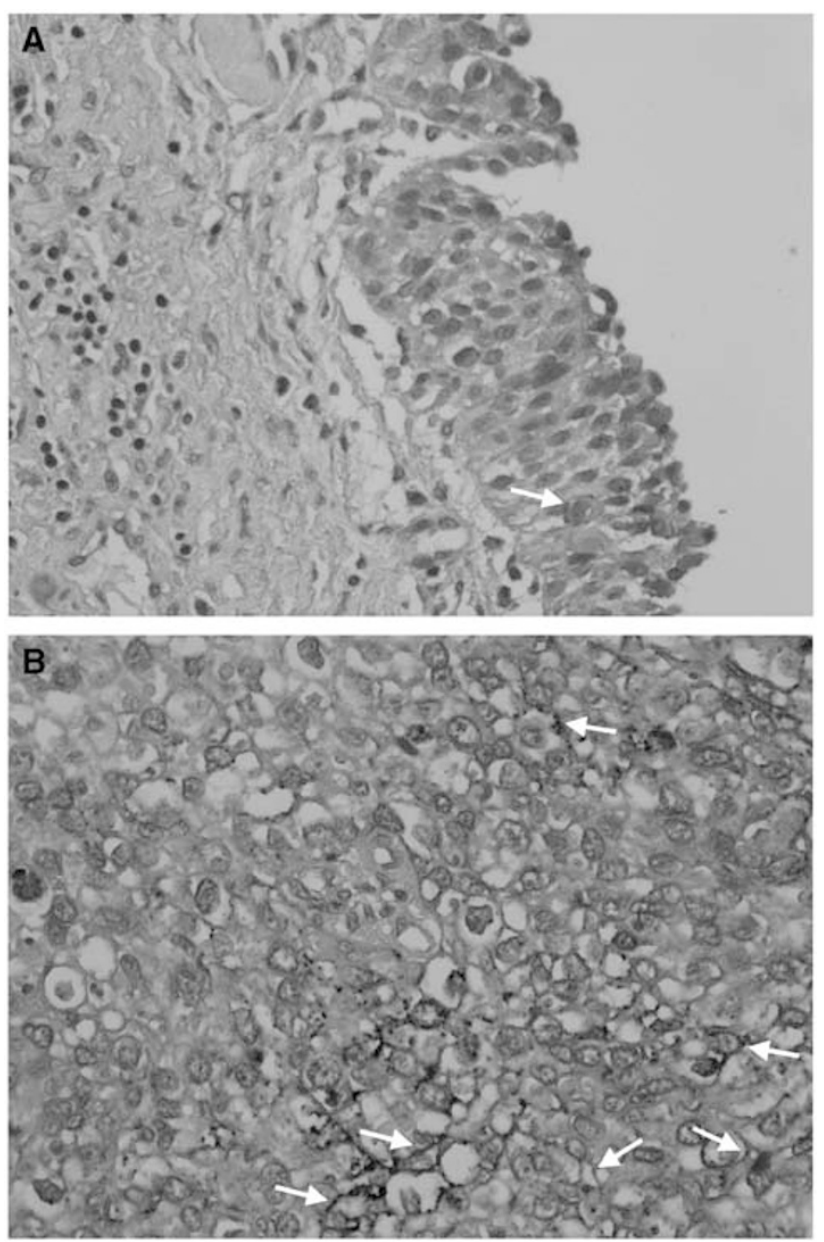

Figure 7 Immunohistochemical expression of $\mathrm{RON}$ protein in the normal urothelium and bladder cancer cells. (A) Membranous expression of $\mathrm{RON}$ receptor was seen in a few non-neoplastic uroepithelial cells (highlighted by arrow). (B) The arrows indicate the membranous staining of RON receptor on cancer cells, representative of a low level of RON expression (original magnification $\times 300$ ).

\section{Effects of RON overexpression on the biological activities} of cancer cells

As RT4 cells are resistant to transfection, UB09 cells expressing a relatively lower level of RON were transfected with plasmid DNA to express exogenous RON protein. The plasmids $(80 \mu \mathrm{g})$ pLp-TRE2-RON and pTet-Lac-Hygo at a molar ratio of $1: 1$ were transfected into UB09 cells using electroporation $(180 \mathrm{~V}, 1000 \mu \mathrm{F})$. The cells were subcultured into a six-well tray $\left(1 \times 10^{4}\right.$ per well $)$ $12 \mathrm{~h}$ later. The cell numbers were counted at a 3-day interval from day 0 through day 9. Overexpression of RON (UB09/RON) induced a higher growth rate of UB09 cells compared to the parental cells $(P=0.0028)$ (Figure 4$)$.

To evaluate the effect of RON upon cell motility, UB09 cells $\left(1 \times 10^{6}\right)$ were transfected and cultured on a cover glass for $24 \mathrm{~h}$. Time-lapse recording was then used to evaluate the progression of wound healing produced by a yellow tip (Ho et al, 2005). The images were recorded every $20 \mathrm{~min}$ for a total of $30-48 \mathrm{~h}$. It showed that UB09/RON cells migrated faster than control cells $(P=0.04)$ (Figure 5).

To test the effect of RON on apoptosis, UB09 cells were first treated with MTX for $48 \mathrm{~h}$ and stained with acridine orange for apoptotic cell measurement. After MTX treatment $\left(50 \mu \mathrm{g} \mathrm{ml}^{-1}\right)$, $60 \%$ of the UB09 cells were apoptotic, but only $25 \%$ of the UB09/ RON cells were apoptotic $(P=0.024)$. The antiapoptotic effect, however, was blocked by wortmannin treatment (10 nM), a P13K inhibitor (Figure 6). Altogether, overexpression of RON increased the growth rate and motility of the cells and conferred an antiapoptotic efficacy on cancer cells through a PI3K-related signaling pathway.

\section{Immunohistochemical expression of RON or MET receptor in primary bladder cancer}

To clarify the clinical significance of RON receptor expression, we studied the IHC expression in a transitional-cell bladder-cancer cohort $(n=183)$. Membranous staining for RON was seen in only a few non-neoplastic urothelial cells (Figure 7a). Overexpression of RON was defined as membranous staining in more than $10 \%$ of tumour cells (Figure $7 \mathrm{~b}$ ). In all, 60 cases $(32.8 \%)$ were classified as overexpression of RON, and $14(23.3 \%)$ of those were high expression (summarised in Table 1). Overexpression of RON was positively associated with histological grading $(P=0.003)$, larger tumours $(P=0.003)$, nonpapillary contour $(P=0.005)$, and tumour stage $(P=0.01)$ using Fisher's exact test or the $\chi^{2}$ test (Table 1).

We also examined the expression of MET in this cohort (Table 1$)$. In total, 82 cases $(44.8 \%)$ overexpressed MET, and 27 (32.9\%) of those were high expression. MET expression was positively associated with histological grading, nonpapillary contour, tumour size, and muscle invasion using Fisher's exact test or the $\chi^{2}$ test $($ all $P<0.001)$. In all study cases, co-expression of both receptors was detected in 35 cases $(19.1 \%)$, and expression of RON or MET was detected in 25 cases (13.7\%), and 47 cases $(25.7 \%)$, respectively (Table 2 ).

\section{Prognostic significance of co-expression of RON and MET in a bladder cancer cohort}

In univariate analysis, none of the biological indicators analysed were correlated with tumour recurrence using the log-rank test $(P>0.1$, respectively) (data not shown), except that muscleinvasive tumours tended to have a higher risk of local recurrence $(P=0.06)$. Factors associated with decreased patient survival were overexpression of RON $(P=0.003)$, co-expression of RON/MET $(P=0.005)$, and overexpression of MET $(P=0.02)$. Patients who co-expressed RON/MET in their bladder tumours had a significantly worse overall survival rate $(P=0.005)$ or metastasis-free survival rate $(P=0.01)$ compared with the remaining expression status of the two receptors (Figure 8).

Multivariate analysis using a logistic regression model revealed that neither biological indicator nor expression of RON or MET or both was associated with tumour recurrence (Table 2). For longterm survival, important prognostic indicators were multiplicity $(P=0.009)$, co-expression of RON/MET $(P=0.03)$, expression of RON $(P=0.04)$, and stage classification $(P=0.05)$ using the logrank test. Overexpression of MET by itself tended to correlate with poor patient survival in this cohort $(P=0.06)$. We next used a Cox proportional hazards models to determine the RR of overall survival with $95 \%$ confidence interval (CI). The RR of poor longterm survival was 2.46 for multiple tumours, 2.22 for co-expression of RON and MET, 2.03 for RON expression alone, and 1.98 for tumour staging.

\section{Significance of co-expression of RON and MET in superficial bladder cancer}

In the subset of superficial bladder cancer (Stages $\mathrm{O}$ and $\mathrm{A}$ ), the frequency of RON and MET overexpression was $19.4 \%$ (18 out of 93) and $32.3 \%$ (30 out of 93), respectively (Table 1 ). Indicators 
Table I Distribution of RON and MET expression, and biological indicators

\begin{tabular}{|c|c|c|c|c|c|c|}
\hline \multirow[b]{2}{*}{ Clinical characteristics } & \multicolumn{3}{|c|}{ RON } & \multicolumn{3}{|c|}{ MET } \\
\hline & Positive (\%) & Negative (\%) & $P$-value & Positive (\%) & Negative (\%) & $P$-value \\
\hline Grade I & $2(1.1)$ & $20(10.9)$ & 0.003 & $4(2.2)$ & $18(9.8)$ & $<0.0001$ \\
\hline Grade II & $22(12.0)$ & $58(31.7)$ & & $25(13.7)$ & $55(30.1)$ & \\
\hline Grade III & $36(19.7)$ & $45(24.6)$ & & $83(45.4)$ & $28(15.3)$ & \\
\hline \multicolumn{7}{|l|}{ Tumour shape } \\
\hline Nonpapillary & $29(15.8)$ & $28(15.3)$ & & $38(20.8)$ & $19(10.4)$ & \\
\hline \multicolumn{7}{|l|}{ Tumour size } \\
\hline$\leqslant 1 \mathrm{~cm}$ & $5(2.7)$ & $31(16.9)$ & 0.003 & $8(4.4)$ & $28(15.3)$ & 0.0004 \\
\hline$>1$ to $\leqslant 3 \mathrm{~cm}$ & $22(12.0)$ & $54(29.5)$ & & $32(17.5)$ & $44(24.0)$ & \\
\hline$>3$ to $\leqslant 5 \mathrm{~cm}$ & $20(10.9)$ & $22(12.0)$ & & $28(15.3)$ & $14(7.7)$ & \\
\hline$>5 \mathrm{~cm}$ & $10(5.5)$ & $7(3.8)$ & & $1 \mid(6.0)$ & $6(3.3)$ & \\
\hline \multicolumn{7}{|l|}{ Stage (TNM staging system) } \\
\hline PTa & $9(4.9)$ & $45(24.6)$ & 0.01 & $13(7.1)$ & $41(22.4)$ & 0.001 \\
\hline PTI & $9(4.9)$ & $30(16.4)$ & & $17(9.3)$ & $22(12.0)$ & \\
\hline pT2a & $16(8.7)$ & $17(9.3)$ & & $23(12.6)$ & $10(5.5)$ & \\
\hline PT2b & $5(2.7)$ & $7(3.8)$ & & $5(2.7)$ & $7(3.8)$ & \\
\hline рT3 & $7(3.8)$ & $5(2.7)$ & & $8(4.4)$ & $4(2.2)$ & \\
\hline $\mathrm{pNI} / \mathrm{pN2}$ & $8(4.4)$ & II (6.0) & & $13(7.1)$ & $6(3.3)$ & \\
\hline $\mathrm{M}+$ & $2(1.1)$ & $2(1.1)$ & & $2(1.1)$ & $2(1.1)$ & \\
\hline$N / A^{a}$ & $4(2.2)$ & $6(3.3)$ & & I (0.5) & $9(4.9)$ & \\
\hline
\end{tabular}

$\mathrm{Cl}=$ confidence interval. $\mathrm{RON}=$ Recepteur d'Origine Nantais. $\mathrm{MET}=\mathrm{c}$-met protein. ${ }^{\mathrm{a}} \mathrm{N} / \mathrm{A}$ : not applicable.

Table 2 Prognostic significance of biological indicators and expression of $\mathrm{RON}$ and/or MET for human bladder cancer patients (multivariate Cox regression analysis)

\begin{tabular}{lclc}
\hline & & \multicolumn{2}{c}{ Survival } \\
\cline { 3 - 4 } Factors & $\begin{array}{c}\text { Recurrence } \\
\text { P-value }\end{array}$ & P-value & RR (95\% Cl) \\
\hline Grade & 0.60 & 0.41 & \\
Stage & 0.14 & $0.05 *$ & $1.98(1.25-3.14)$ \\
Size & 0.19 & 0.35 & \\
Shape & 0.85 & 0.60 & \\
Multiplicity & 0.88 & $0.009 *$ & $2.46(1.19-3.55)$ \\
RON & 0.28 & $0.04 *$ & $2.03(1.08-3.53)$ \\
MET & 0.40 & 0.06 & $2.22(1.19-3.74)$ \\
RON/MET & 0.38 & $0.03 *$ & 2.020
\end{tabular}

$\mathrm{Cl}=$ confidence interval. $\mathrm{RON}=$ Recepteur d'Origine Nantais. $\mathrm{MET}=\mathrm{c}$-met protein. $* P \leqslant 0.05$.

associated with poor overall survival were co-expression of RON and MET $(P=0.03)$ and multiplicity $(P=0.05)$, with RR estimated at $3.43(95 \%$ CI $1.16-10.12)$ and 2.22 (95\% CI 1.01-4.91), respectively (data not shown). But expression of RON or MET or both did not predict the chance of long-term survival for patients with muscle-invasive tumours.

\section{DISCUSSION}

In this study, we found that expression of RON or MET, or both, is positively associated with aggressive biological indicators and

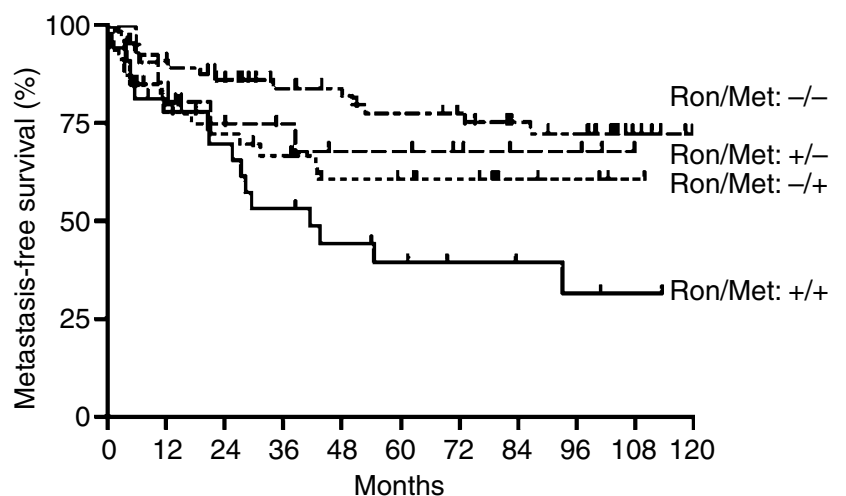

Figure 8 Prognostic significance of RON and/or MET expression in bladder cancer patients. Patients who co-expressed RON and MET had a significantly worse metastasis-free survival compared with patients who had single-receptor-positive tumours or no receptor expression $(P=0.0 \mathrm{I})$.

decreased patient survival, which supports the hypothesis that RON-related signalling events play an important role in the progression of bladder cancer. Our results are substantially in agreement with studies on primary carcinomas of the breast (Maggiora et al, 1998), colorectum (Zhou et al, 2003), liver (Chen et al, 1997), and ovary (Maggiora et al, 2003). Moreover, our in vitro experiments indicated that increased cell growth or motility and the antiapoptotic effect are the underlying mechanisms for RON in bladder carcinogenesis. These results are consistent with reports showing a mitogenic/invasive response induced by constitutive activation of RON (Santoro et al, 1996) and activation 
of signalling pathways, including PI3K, in regulating cell adhesion, motility, growth, and survival after stimulation with MSP (Danilkovitch et al, 2000; Peace et al, 2001).

The most intriguing observation of this investigation, however, is the prognostic importance of the co-expression of RON and MET, especially for patients with superficial bladder cancer $(P=0.03 ; \mathrm{RR}=3.43)$. This observation has clinical implications because this group of patients represents the largest group of urological malignancy in common practice. Co-expression of both receptors thus appears to signify a distinctive 'invasive growth' programme for carcinoma cells. This conclusion essentially concurs with the current hypothesis of crosstalk between subfamily members of the ErbB receptors and their prognostic significance (Wada et al, 1990; Sliwkowski et al, 1994; PinkasKramarski et al, 1996; Chow et al, 2001). Therefore, evaluation of the RON and MET expression status may identify a subset of bladder cancer patients who might require more intensive treatment.

Further support for clinical relevance of RON/MET interaction in human cancer comes from in vitro experiments by Follenzi et al (2000). First, MET and RON exist on the cell membrane surface as preformed dimers before ligand stimulation, and there is a bidirectional transphosphorylation between MET and RON after stimulation with either hepatocyte growth factor or MSP. Second, although RON is a less efficient kinase than MET, formation of MET/RON complexes induces a more efficient RON transphosphorylation by MET, leading to a more sustained signal than that induced by the RON/RON homodimer. Activation of both MET and RON may thus possibly initiate a cooperative or synergistic response to their ligands. Further investigation is mandatory to clarify the benefits of combined therapies against RON/MET receptors and their signal transducers.

In our series, the most important prognostic indicators for bladder cancer patients were, first, multiple tumours at diagnosis and, second, advanced tumour stage. A similar discovery was also reported in some earlier studies (Holmang et al, 1995; Crew et al, 1997; Cheng et al, 2002), although no complete rationale was proposed to explain for the occurrence. Since dysplastic change in the field mucosa correlates well with clinical outcome in cancer patients, multiple tumours at diagnosis may represent a sign of unstable urothelium. Alternatively, if multiple bladder cancers are monoclonal in origin (Sidransky et al, 1992), the occurrence might signify an intraluminal spreading and implantation of tumour cells. A prospective study is necessary to verify the consequences of such spreading and implantation before determining what might be appropriate treatment plans for bladder cancer patients.

In summary, the results of our study indicate that RON-related molecular events are important in the progression of bladder carcinogenesis. Evaluation of the expression pattern of MET and RON is of great help in selecting bladder cancer patients for more aggressive therapy.

\section{ACKNOWLEDGEMENTS}

This study was supported by grants NSC91-2320-B-006-056 and NSC91-2321-B-006-003 from the National Science Council, and by grant 91-B-FA09-1-4 from the Ministry of Education Program for Promoting Academic Excellence in Universities, Taiwan.

\section{REFERENCES}

Adam RM, Roth JA, Cheng HL, Rice DC, Khoury J, Bauer SB, Peters CA, Freeman MR (2003) Signaling through PI3K/Akt mediates stretch and PDGF-BB-dependent DNA synthesis in bladder smooth muscle cells. J Urol 169: 2388-2393

Angeloni D, Danilkovitch-Miagkova A, Ivanov SV, Breathnach R, Johnson BE, Leonard EJ, Lerman MI (2000) Gene structure of the human receptor tyrosine kinase RON and mutation analysis in lung cancer samples. Genes Chromosomes Cancer 29: 147-156, doi: 10.1002/1098-2264 (2000)9999:9999 < ::AID-GCC1015>3.0.CO;2-N

Chen Q, Seol DW, Carr B, Zarnegar R (1997) Co-expression and regulation of Met and Ron proto-oncogenes in human hepatocellular carcinoma tissues and cell lines. Hepatology 26: 59-66, doi: 10.1002/ hep. 510260108

Chen YQ, Zhou YQ, Fisher JH, Wang MH (2002) Targeted expression of the receptor tyrosine kinase RON in distal lung epithelial cells results in multiple tumor formation: oncogenic potential of RON in vivo. Oncogene 21: $6382-6386$, doi: 10.1038/sj.onc. 1205783

Cheng HL, Trink B, Tzai TS, Liu HS, Chan SH, Ho CL, Sidransky D, Chow $\mathrm{NH}$ (2002) Overexpression of c-met as a prognostic indicator for transitional cell carcinoma of the urinary bladder. A comparison with p53 nuclear accumulation. J Clin Oncol 20: $1544-1550$

Chow NH, Chan SH, Tzai TS, Ho CL, Liu HS (2001) Expression profiles of ErbB family receptors and prognosis in primary transitional cell carcinoma of the urinary bladder. Clin Cancer Res 7: 1957-1962

Chow NH, Lin YJ, Cheng HL, Tzai TS, Ho CL, Chang TY, Dai YC, Liu HS (2003) The significance of macrophage stimulating protein (MSP)/RON signaling pathway in the progression of human bladder cancer. Proc Am Assoc Cancer Res 44: 397 (abstract)

Collesi C, Santoro MM, Gaudino G, Comoglio PM (1996) A splicing variant of the RON transcript induces constitutive tyrosine kinase activity and an invasive phenotype. Mol Cell Biol 16: 5518-5526

Crew JP, O'Brien T, Bradburn M, Fuggle S, Bicknell R, Cranston D, Harris AL (1997) Vascular endothelial growth factor is predictor of relapse and stage progression in superficial bladder cancer. Cancer Res 57: 5281-5285

Danilkovitch A, Donley S, Skeel A, Leonard EJ (2000) Two independent signaling pathways mediate the antiapoptotic action of macro- phage-stimulating protein on epithelial cells. Mol Cell Biol 20: $2218-2227$

Eble JN, Sauter G, Epstein JI, Sesterhenn IA (2004) World Health Organization Classification of Tumors. Pathology and Genetics of Tumours of the Urinary System and Male Genital Organs. Lyon: IARC Press

Follenzi A, Bakovic S, Gual P, Stella MC, Longati P, Comoglio PM (2000) Cross-talk between the proto-oncogenes Met and Ron. Oncogene 19: $3041-3049$

Heldin CH (1995) Dimerization of cell surface receptors in signal transduction. Cell 80: 213-223

Ho CL, Tsai YC, Hsu YH, Chen HW, Liu HS, Chang YC, Chow NH (2005) Mini chamber system for long-term maintenance and observation of cultured cells. Biotechniques 38: 267-273

Holmang S, Hedelin H, Anderstrom C, Johansson SL (1995) The relationship among multiple recurrences, progression and prognosis of patients with stages $\mathrm{Ta}$ and $\mathrm{T} 1$ transitional cell cancer of the bladder followed for at least 20 years. J Urol 153: $1823-1827$

Koo SH, Kwon KC, Ihm CH, Jeon YM, Park JW, Sul CK (1999) Detection of genetic alterations in bladder tumors by comparative genomic hybridization and cytogenetic analysis. Cancer Genet Cytogenet 110: 87 -93, doi: 10.1016/S0165-4608(98)00193-9

Maggiora P, Lorenzato A, Fracchioli S, Costa B, Castagnaro M, Arisio R, Katsaros D, Massobrio M, Comoglio PM, Flavia Di Renzo M (2003) The RON and MET oncogenes are co-expressed in human ovarian carcinomas and cooperate in activating invasiveness. Exp Cell Res 288: 382 - 389, doi: 10.1016/S0014-4827(03)00250-7

Maggiora P, Marchio S, Stella MC, Giai M, Belfiore A, De Bortoli M, Di Renzo MF, Costantino A, Sismondi P, Comoglio PM (1998) Overexpression of the RON gene in human breast carcinoma. Oncogene 16: $2927-2933$

Peace BE, Hughes MJ, Degen SJ, Waltz SE (2001) Point mutations and overexpression of Ron induce transformation, tumor formation, and metastasis. Oncogene 20: $6142-6151$

Pinkas-Kramarski R, Shelly M, Glathe S, Ratzkin BJ, Yarden Y (1996) Neu differentiation factor/neuregulin isoforms activate distinct receptor combinations. J Biol Chem 271: 19029-19032 
Rampino T, Collesi C, Gregorini M, Maggio M, Soccio G, Guallini P, Dal Canton A (2002) Macrophage-stimulating protein is produced by tubular cells and activates mesangial cells. J Am Soc Nephrol 13: 649-657

Ronsin C, Muscatelli F, Mattei MG, Breathnach R (1993) A novel putative receptor protein tyrosine kinase of the met family. Oncogene 8: 11951202

Rossi MR, Masters JR, Park S, Todd JH, Garrett SH, Sens MA, Somji S, Nath J, Sens DA (2001) The immortalized UROtsa cell line as a potential cell culture model of human urothelium. Environ Health Perspect 109: $801-808$

Santoro MM, Collesi C, Grisendi S, Gaudino G, Comoglio PMe (1996) Constitutive activation of the RON gene promotes invasive growth but not transformation. Mol Cell Biol 16: $7072-7083$

Sidransky D, Frost P, Von Eschenbach A, Oyasu R, Preisinger AC, Vogelstein B (1992) Clonal origin of bladder cancer. N Engl J Med 326: $737-740$

Sliwkowski MX, Schaefer G, Akita RW, Lofgren JA, Fitzpatrick VD, Nuijens A, Fendly BM, Cerione RA, Vandlen RL, Carraway III KL (1994) Coexpression of erbB2 and erbB3 proteins reconstitutes a high affinity receptor for heregulin. J Biol Chem 269: $14661-14665$
Sobin LH, Wittekind C (2002) UICC TNM Classification of Malignant Tumours. New York: Wiley-Liss

Wada T, Qian XL, Greene MI (1990) Intermolecular association of the p185neu protein and EGF receptor modulates EGF receptor function. Cell 61: $1339-1347$

Wang MH, Ronsin C, Gesnel MC, Coupey L, Skeel A, Leonard EJ, Breathnach R (1994) Identification of the ron gene product as the receptor for the human macrophage stimulating protein. Science 266: $117-119$

Yan L, Borregaard N, Kjeldsen L, Moses MA (2001) The high molecular weight urinary matrix metalloproteinase (MMP) activity is a complex of gelatinase B/MMP-9 and neutrophil gelatinase-associated lipocalin (NGAL). Modulation of MMP-9 activity by NGAL. J Biol Chem 276: 37258-37265

Zhou YQ, He C, Chen YQ, Wang D, Wang MH (2003) Altered expression of the RON receptor tyrosine kinase in primary human colorectal adenocarcinomas: generation of different splicing RON variants and their oncogenic potential. Oncogene 22: 186-197, doi: 10.1038/ sj.onc. 1206075 . 